\title{
Methods for thermal inactivation of pathogens in mozzarella: a comparison between stretching and pasteurization
}

\author{
[Métodos para inativação térmica de patógenos em mozarela: comparação \\ entre filagem e pasteurização] \\ D.C. Raimundo, R.G. Travaglini, G.O. Souza, K.R. Starikoff, S.A. Sanches, \\ O.B. Souza, S.C. Balian, E.O. Telles \\ Universidade de São Paulo - Faculdade de Medicina Veterinária e Zootecnia - São Paulo, SP
}

\begin{abstract}
This study aimed to evaluate the efficiency of stretching in the reduction of pathogens when compared to milk pasteurization, the official method to ensure safe cheese production. Whole buffalo milk was contaminated with Mycobacterium fortuitum, Listeria monocytogenes, Salmonella typhimurium, and Staphylococcus aureus. Part of the milk was used in mozzarella production and the other part was submitted to holder pasteurization. Pathogens were quantified before and after thermal processing (mozzarella stretching and milk pasteurization). Pasteurization and stretching led to the following reductions in log cycles, respectively: 4.0 and 6.3 for Mycobacterium sp.; 6.0 and 8.4 for Listeria sp.; $>6.8$ and 4.5 for Staphylococcus sp.; and >8.2 and 7.5 for Salmonella sp.
\end{abstract}

Keywords: mozzarella, stretching, pasteurization, pathogenic bacteria

\section{RESUMO}

Este estudo teve como objetivo avaliar a eficácia da filagem na redução de patógenos, em comparação com a pasteurização do leite, que é o método oficial para garantir a produção de queijos seguros. Leite de búfala integral foi contaminado com Mycobacterium fortuitum, Listeria monocytogenes, Salmonella typhimurium e Staphylococcus aureus. Parte desse leite foi empregada na fabricação da mozarela $e$ outra parte foi submetida à pasteurização lenta. Os patógenos foram quantificados antes e após os processos térmicos (filagem da mozarela e pasteurização do leite). As reduções, em ciclos logarítmicos, causadas pela pasteurização e pela filagem, respectivamente, foram: 4,0 e 6,3 de Mycobacterium sp., 6,0

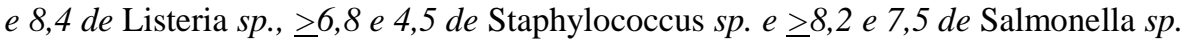

Palavras-chave: mozzarella, filagem, pasteurização, bactérias patogênicas

\section{INTRODUCTION}

Buffalo mozzarella is a typical pasta filata cheese, which means that ripened curd is coarsely milled, melted in hot water, and stretched. The result is an elastic and kneadable cheese mass with a filiform structure (Walstra et al., 1999). Although milk pasteurization is mandatory for the production of cheeses that are aged for less than a 60 days, such as buffalo mozzarella (Brazil, 1952), this is not always observed. Therefore, an evaluation of the microbicide potential of stretching has become relevant from the perspective of Microbiological Risk Assessment.

Under this perspective, this study aimed to evaluate the efficiency of buffalo mozzarella stretching in the inactivation of Mycobacterium fortuitum, Listeria monocytogenes, Salmonella typhimurium, and Staphylococcus aureus in experimentally contaminate milk, compared with the effect of milk pasteurization on the same agents.

Recebido em 14 de outubro de 2011

Aceito em 20 de novembro de 2012

E-mail: danielecraimundo@gmail.com 


\section{MATERIALS AND METHODS}

Milk samples were obtained from a buffalo farm located in the Sorocaba region, in São Paulo, Brazil, and maintained at $4{ }^{\circ} \mathrm{C}$. Two aliquots were taken to determine fat content (Brazil, 2006) and the presence of Mycobacterium spp., Listeria monocytogenes; Staphylococcus aureus, and Salmonella spp.

Buffalo mozzarella was manufactured with $M$. fortuitum (NCTN 8573), Listeria monocytogenes (ATCC 19115, 4b), Staphylococcus aureus (ATCC 25923), and Salmonella typhimurium (ATCC 14028). The decision to use Mycobacterium fortuitum instead of Mycobacterium bovis in this study was due to observations that both species show similar thermal inactivation kinetics (Grant et al., 1996), and to the fact that $M$. fortuitum grows faster and is less pathogenic to human beings than $M$. bovis, posing less risk to the handler (WHO, 1984).

In order to be able to isolate this single variable (the effect of stretching), only one batch of cheese was made. Curd was milled, homogenized, and then divided into five portions to be stretched. Samples of curd and stretched mass were collected for the enumeration of the bacteria.

The same procedure was done with pasteurization: one batch was contaminated and five portions were submitted to holder pasteurization $\left(65^{\circ} \mathrm{C} / 30\right.$ minutes $)$ in a water bath.

Working culture was prepared by growing $M$. fortuitum for seven days in a Lowënstein-Jensen medium at $37^{\circ} \mathrm{C}$. Approximately $0.600 \mathrm{~g}$ of the culture was vigorously homogenized with $1 \mathrm{~mL}$ of $0.85 \%$ saline and $0.05 \%$ Tween 80 solution. After that, $24 \mathrm{~mL}$ of $0.85 \%$ saline solution were added to the flask (containing glass beads to prevent cell clumping), yielding a $25 \mathrm{~mL}$ inoculum.

L. monocytogenes, S. typhimurium, S. aureus were inoculated individually into BHI (Brain Heart Infusion, Difco, USA) broth, incubated at $37^{\circ} \mathrm{C}$ for 24 hours and inoculated onto agar, as these microorganisms are grown as a culture on semisolid agar. L. monocytogenes was inoculated on Palcam, S. typhimurium on Brilliant Green Bile with lactose (2\%), and S. aureus on a Baird-
Parker agar base. All cultures were incubated at $37^{\circ} \mathrm{C}$ for 24 hours, and then two colonies of each agent were inoculated individually in BHI broth and incubated at $37^{\circ} \mathrm{C}$ for 24 hours.

Mozzarella was produced in the laboratory from 5 liters of milk, which was heated to $38^{\circ} \mathrm{C}$ and contaminated with $15.0 \mathrm{~mL}$ of the $M$. fortuitum inoculum, and $7.5 \mathrm{~mL}$ of each of the $L$. monocytogenes, S. typhimurium, and S. aureus inocula.

Contaminated milk received an addition of $5.0 \mathrm{~mL}$ of starter culture (FDST-M7, Chr. Hansen, Denmark). After 30 minutes, an addition of $1.5 \mathrm{~mL}$ of rennet (Estrella ,Chr. Hansen, Denmark) diluted $1: 15$, to induce coagulation. Forty-five minutes later, curd was cut, and whey was partially removed. Curd was ripened for about 4.5 hours. After that, curd was milled, melted in hot water (above $90^{\circ} \mathrm{C}$ ), and stretched to form a smooth and shiny mass. Samples of curd and stretched mass were collected (25g each) for microbiological analysis.

To evaluate the efficiency of holder pasteurization, $100 \mathrm{~mL}$ of the milk was contaminated with $4 \mathrm{~mL}$ of the $M$. fortuitum inoculum and $0.2 \mathrm{~mL}$ each of the $L$. monocytogenes, S. typhimurium, and $S$. aureus inocula. After homogenization, milk was distributed into $11(16 \times 160 \mathrm{~mm})$ tubes $(5 \mathrm{~mL}$ in each tube). One of the tubes was used for microbiological counts in milk before pasteurization, and the other 10 were used for 5 pasteurization assays using 2 tubes for each repetition.

Pasteurization was performed in a water bath (Unitemp, Fanen, Brazil) at $65^{\circ} \mathrm{C}$, with submersion of the entire tube surface, except for the plug. One of the tubes was removed when milk temperature reached $65^{\circ} \mathrm{C}$ (time 0 ) and the other, 30 minutes later. Once removed from the water bath, the tubes were immediately put in an ice bath and kept in the refrigerator until the moment of analysis.

To assess milk temperature, a thermometer was attached to a tube with $5 \mathrm{~mL}$ of non-contaminated raw milk. To control the pasteurization process, three samples of non-contaminated raw milk $(5 \mathrm{~mL}$ each) were used in every repetition to evaluate the presence of the enzymes peroxidase 
(Peroxidase leite- tiras, Laborclin, Brazil) (Brazil, 2006) and alkaline phosphatase (Fosfatase Alkalina leite- tiras, Laborclin, Brazil) at the end of the thermal treatment.

Samples were submitted to serial 10-fold dilutions in peptone water $(0.1 \%)$, and inoculated into media specific for each agent.

Mycobacterium fortuitum: $0.1 \mathrm{~mL}$ of each dilution was inoculated in duplicate on the surface of modified Lowenstein-Jensen medium (Centro Panamericano de Zoonosis, 1985). The modification by Donaghy et al. (2003) was adapted to our procedure. To suppress lactic bacteria, the following antibiotics were added to the medium before distribution and coagulation: amphotericin B $(5 \mu \mathrm{g} / \mathrm{mL})$, nalidixic acid $(60 \mu \mathrm{g} / \mathrm{mL})$, polymyxin B $(50 \mathrm{U} / \mathrm{mL})$, and trimethoprim $(5 \mu \mathrm{g} / \mathrm{mL})$. Inoculated plates were incubated at $37^{\circ} \mathrm{C}$ for 5 days (Koneman et al., 2001). Dilutions that presented between 15 and 150 colonies were used for counts.

Listeria monocytogenes: The previously published methodology (Brazil, 2003) was adapted to obtain the MPN (Most Probable Number)/mL or g. UVM broth and Frazer broth were used as enrichment steps followed by streaking onto plates of Palcam. Every colony that had characteristics of the agent on the corresponding agar was assumed to be Listeria.

Staphylococcus aureus: The official methodology (Brazil, 2003) was used, and all colonies with characteristics of the agent in the medium were assumed to be Staphylococcus. The dilution chosen for counting was the one that presented between 25 and 250 colonies.

Salmonella typhimurium: Colonies were counted using the adapted MPN method (Brazil, 2003), as follows: pre-enrichment was carried out in peptone water $(1 \%)$; selenite cystine broth was used as selective enrichment and, after that, enriched cultures were streaked on Brilliant
Green Lactose Bile (BGB) plates. The presence of at least one characteristic colony of Salmonella in the BGB plates was considered to be positive for the bacteria.

All results were transformed into a CFU or MPN log per milliliter or gram.

\section{RESULTS AND DISCUSSION}

Listeria spp. (in 25mL), Salmonella spp. (in 25mL), Mycobacterium spp. (in $1 \mathrm{~mL}$ ) and Staphylococcus spp. (in $1 \mathrm{~mL}$ ) were absent in raw milk with $6.0 \%$ fat.

The enzymatic analysis of holder pasteurization showed that the process caused inactivation of the alkaline phosphatase in milk but did not have a significant effect on peroxidase, which is in accordance to the Brazilian official regulations.

Table 1, shows the results of the microbiological counts (in log of MPN or CFU per g or $\mathrm{mL}$ ) for both holder pasteurization and stretching, and Tab. 2, summarizes the lethal effects of both processes on the inoculated agents. Considering that water activity $\left(\mathrm{a}_{\mathrm{w}}\right)$ and salt content are not hurdles for these agents in this product (mozzarella is a fresh, soft cheese, and no salt was added), they did not influence the survival of the microorganisms, but the acidity in the curd could negatively affect their thermal resistance (Jay, 2000).

Pasteurization caused a 4-log cycle reduction in Mycobacterium sp., 6-log cycles in Listeria sp. and complete destruction of the inocula of Staphylococcus sp. (reduction $\geq 6.8$ cycles) and Salmonella sp. (reduction $\geq 8.2$ cycles).

It is interesting to observe that the heating phase of pasteurization (until milk reached $65^{\circ} \mathrm{C}$ ) produced an important lethal effect on Listeria sp., Staphylococcus sp. and especially Salmonella sp (Table 2), but not on Mycobacterium sp. 
Table 1. Listeria monocytogenes. Mycobacterium fortuitum, Staphylococcus aureus, and Salmonella typhimurium counts in milk before holder pasteurization, in the curd before stretching, and average counts of the agents in milk (beginning and end of pasteurization) and in the mass after stretching.

\begin{tabular}{|c|c|c|c|c|c|c|}
\hline 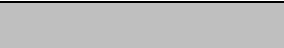 & \multicolumn{3}{|c|}{ Pasteurization } & \multicolumn{3}{|c|}{ Stretching } \\
\hline & Repetition & Before & $\begin{array}{l}\text { Beginning } \\
\text { (T0)* }\end{array}$ & End $(\mathrm{T} 30)^{* *}$ & Before & After \\
\hline & 1 & & 3.0 & $0.0 \S$ & & 0.0 \\
\hline Listeria & 2 & & 3.0 & 0.7 & & 0.0 \\
\hline monocytogenes & 3 & 6.6 & 2.6 & 1.4 & 8.4 & 0.15 \\
\hline \multirow{4}{*}{$\log \mathrm{MPN} / \mathrm{mL}$ or $\mathrm{g} I$} & 4 & & 3.0 & 0.7 & & 0.0 \\
\hline & 5 & & 3.0 & 0.0 & & 0.0 \\
\hline & average & & 2.9 & 0.6 & & 0.03 \\
\hline & 1 & & 5.4 & 3.3 & & 0.0 \\
\hline Mycobacterium & 2 & & 6.2 & 3.4 & & 4.7 \\
\hline fortuitum & 3 & 7.7 & 7.9 & 3.9 & 7.7 & 2.3 \\
\hline \multirow[t]{4}{*}{$\log \mathrm{CFU} / \mathrm{mL}$ or $\mathrm{g} \dagger$} & 4 & & 7.9 & 4.1 & & 0.0 \\
\hline & 5 & & 6.4 & 4.0 & & 0.0 \\
\hline & average & & 6.8 & 3.7 & & 1.4 \\
\hline & 1 & & 1.0 & 0.0 & & 1.7 \\
\hline Staphylococcus & 2 & & 3.4 & 0.0 & & 3.0 \\
\hline aureus & 3 & 6.8 & 3,4 & 0.0 & 6.7 & 0.0 \\
\hline \multirow[t]{4}{*}{$\log \mathrm{CFU} / \mathrm{mL}$ or $\mathrm{g}$} & 4 & & 3.4 & 0.0 & & 3.3 \\
\hline & 5 & & 4.6 & 0.0 & & 2.9 \\
\hline & average & & 3.2 & 0.0 & & 2.2 \\
\hline & 1 & & 0.7 & 0.0 & & 0.0 \\
\hline Salmonella & 2 & & 2.6 & 0.0 & & 0.7 \\
\hline typhimurium & 3 & 8.2 & 1.2 & 0.0 & 7.6 & 0.0 \\
\hline \multirow[t]{3}{*}{$\log \mathrm{MPN} / \mathrm{mL}$ or $\mathrm{g}$} & 4 & & 1.4 & 0.0 & & 0.0 \\
\hline & 5 & & 2.0 & 0.0 & & 0.0 \\
\hline & average & & 1.6 & 0.0 & & 0.14 \\
\hline
\end{tabular}

* when milk reached $65^{\circ} \mathrm{C}$. ** at the end of pasteurization.

II most probable number per milliliter or gram

$\uparrow$ colony forming unit per milliliter or gram

$\S$ indicates that the contamination was lower than the limit of detection for the method used, i.e.: $<0.3 \mathrm{MPN} / \mathrm{mL}$ or $\mathrm{g}$ or $<0.5 \mathrm{CFU} / \mathrm{mL}$ or $\mathrm{g}$.

Table 2. Reduction (in log cycles) of the population of Listeria monocytogenes, Mycobacterium fortuitum, Staphylococcus aureus, and Salmonella typhimurium for holder pasteurization (heating phase and complete process) and stretching

\begin{tabular}{lllc} 
& \multicolumn{1}{c}{$\begin{array}{c}\text { Pasteurization } \\
\left.\text { (up to } 65^{\circ} \mathrm{C}\right)\end{array}$} & $\begin{array}{l}\text { Complete process } \\
\text { (heating phase } \\
\left.+30 \mathrm{~min} / 65^{\circ} \mathrm{C}\right)\end{array}$ & 8.4 \\
\hline $\begin{array}{l}\text { Listeria monocytogenes } \\
\text { (log MPN/mL or g) II }\end{array}$ & 3.7 & 6 & 6.3 \\
$\begin{array}{l}\text { Mycobacterium fortuitum } \\
\text { (log CFU/mL or g) } \dagger\end{array}$ & 0.9 & 4 & 4.5 \\
$\begin{array}{l}\text { Staphylococcus aureus } \\
\text { (log CFU/mL or g) }\end{array}$ & 3.6 & $\geq 6.8$ & 7.5 \\
$\begin{array}{l}\text { Salmonella typhimurium } \\
\text { (log MPN/mL or g) }\end{array}$ & 6.6 & $\geq 8.2$ & \\
\hline
\end{tabular}

II most probable number per milliliter or gram

$\dagger$ colony forming unit per milliliter or gram 
Stretching was more efficient than pasteurization in the inactivation of Mycobacterium sp. and Listeria sp., but curiously, the opposite occurred with Salmonella and especially with Staphylococcus sp. Stretching inactivated 6.3 logarithmic cycles of Mycobacterium sp., 8.37 cycles of Listeria sp., 7.46 cycles of Salmonella sp., and only 4.5 cycles of Staphylococcus sp. The greater efficiency of stretching could be explained by the fact that microorganisms were already injured by curd acidity (Jay, 2000), but this explanation does not elucidate the behavior of Salmonella sp. and Staphylococcus sp. under the same conditions. It is possible that these microorganisms are less sensitive to acid injury than the others.

The maximum natural contamination of milk by M. bovis is $10^{4} \mathrm{CFU} / \mathrm{mL}$ (Ball, 1943), and it ranges from $10^{3}$ to $10^{6} \mathrm{CFU} / \mathrm{mL}$ for $L$. monocytogenes (Bemrah et al., 1998). In these conditions, milk submitted to holder pasteurization would end up with $1 \mathrm{CFU} / \mathrm{mL}$ of $M$. bovis and from $10^{-3}$ to $1 \mathrm{CFU} / \mathrm{mL}$ of $L$. monocytogenes (depending on the initial load) after the thermal process. Curd mass with this level of contamination would present, after stretching, $<10^{-2} \mathrm{CFU}$ of $M$. bovis per gram and, in the case of L. monocytogenes, $<10^{-5}$ to $<10^{-2}$ $\mathrm{CFU} / \mathrm{g}$.

It is worth pointing out that national regulations do not define acceptable counts for $M$. bovis, but require absence of Listeria monocytogenes and Salmonella spp. in 25 grams of cheeses like mozzarella, which mean $<4 \times 10^{-2} \mathrm{CFU}$ per gram. The same regulations allow up to $10^{3} \mathrm{CFU}$ of Staphylococcus aureus per gram of product (Brazil, 2001).

Regardless of our results, $M$. bovis and $M$. fortuitum were completely inactivated by holder pasteurization in the studies published by Kells and Lear (1960), Harrington and Karlson (1965), and Grant et al. (1996). Data on the reduction of Mycobacterium avium subsp. paratuberculosis vary from 2 to $5 \log$ cycles, when submitted to pasteurization at $63^{\circ} \mathrm{C}$ for 30 minutes (Paolicchi, 2008).

Holder pasteurization of cow and goat whole-fat milk contaminated with $M$. fortuitum (NCTN 8573) caused an average reduction of $3.9 \log$ cycles and $4.4 \log$ cycles of $\mathrm{CFU} / \mathrm{mL}$, respectively (Nishimoto, 2006; Starikoff, 2006). Both authors observed that the heating phase (until milk reaches $65^{\circ} \mathrm{C}$ ) caused an average reduction of $2.0 \mathrm{log}$ cycles and $0.3 \mathrm{log}$ cycles of the agent in cow and goat milk, respectively. These data are similar to those of this study, also showing that the substrate has an important effect on thermal destruction characteristics of this agent.

Reductions of Listeria monocytogenes and Staphylococcus aureus caused by pasteurization that were lower than those observed in the present study were described in literature. Reductions of 4 to 5 logarithmic cycles of Listeria sp. (MacDonald and Sutherland, 1993) and of 2 cycles of Staphylococcus at $63^{\circ} \mathrm{C}$ for 20 minutes (Ambrosili, 1991) were reported. However, results similar to those obtained in this study were observed with Salmonella javiana, with reductions of more than 9 logarithmic cycles (Eckner et al., 1990).

Stretching has already been evaluated as a thermal treatment to improve the sanitary quality of cheese (Caserio et al., 1977; Eckner et al., 1990; Villani et al., 1996; Kim et al., 1998; Silva et al., 1999; Spano et al., 2003) but there are few reports, and none of them studied the behavior of Mycobacterium after this treatment.

Eckner et al. (1990) showed full inactivation of $S$. javiana by stretching, starting from an inoculum of $10^{5} \mathrm{CFU} / \mathrm{mL}$ in milk, an efficiency that was similar to the one obtained for Salmonella in this study.

However, literature presents different data on the behavior of Salmonella typhimurium and Staphylococcus aureus, with reductions of about 2 and 5 logarithmic cycles, respectively (Caserio et al., 1977), while Listeria monocytogenes showed about 2-log cycle reduction (Villani et al., 1996). A reduction of about 3 logarithmic cycles of coagulase-positive Staphylococcus was reported by Silva (1997).

In this study, Mycobacterium sp. showed more resistance to pasteurization than Listeria sp., Salmonella sp. or Staphylococcus sp., an expected finding, once Mycobacterium is considered to be the most resistant nonsporeforming bacteria that may contaminate milk (Behmer, 1991). The surprising fact was 
Staphylococcus aureus showing more resistance to stretching than the other microorganisms analyzed.

A first analysis of the results obtained in this study might suggest that mozzarella production from raw milk is safe. However, when the results of stretching are analyzed in relation to Mycobacterium sp. and Staphylococcus sp. separately, we observed that the efficiency of the process varied.

This variation becomes more relevant when we take into consideration that in real continuous production, other variables may influence the efficiency of the process. Microbiological characteristics of the milk, curd ripening point, water temperature, water: mass ratio during stretching, as well as the contact period between mass and water, examples of variables that may interfere with the final result. Caserio et al. (1977) and Villani et al. (1996) also emphasized that stretching presents an irregular time/temperature profile that might compromise its efficiency in microbial load reduction.

\section{CONCLUSION}

Under the conditions of this study, mozzarella stretching was more efficient than milk pasteurization in reducing the inocula of Listeria monocytogenes, Mycobacterium fortuitum, and Salmonella typhimurium, but it was less efficient in the elimination of Staphylococcus aureus. Data suggest that a mozzarella production flowchart based on stretching as the only phase for elimination of pathogenic microorganisms might not ensure the necessary safety of the product.

\section{ACKNOWLEDGMENTS}

CNPq - Conselho Nacional de Desenvolvimento Científico e Tecnológico.

\section{REFERENCES}

AMBROSILI, R. Effetto della pastorizzazione in caldaia su batteri di interesse igienico-sanitario in alcuni caseifici artigianali. Annali di microb. ed enzimol., v.41, p.237-242, 1991.
BALL, C.O. Short-time pasteurization of milk. Ind. Eng. Chem., v.35, p.71-84, 1943.

BEHMER, M.L.A. Tecnologia do leite. Brasil: NOBEL, 1991. 320p.

BEMRAH, N.; SANAA, M.; CASSIN, M.H.; et al. Quantitative risk assessment of human listeriosis from consumption of cheese made from raw milk. Prev. Vet. Med., v.37, p.129-145, 1998.

BRASIL. Ministério da Agricultura, Pecuária e Abastecimento. Aprova o Regulamento da Inspeção Industrial e Sanitária dos Produtos de Origem Animal. Diário Oficial da União, Brasília, 07 de julho de 1952. Seção 1.

BRASIL. Agência Nacional de Vigilância Sanitária - ANVISA. Resolução n ${ }^{\circ} 12$ de 02 de janeiro de 2001. Aprova o Regulamento Técnico sobre padrões microbiológicos para alimentos. Diário Oficial da União, Brasília, 10 de janeiro, 2001. Seção 1

BRASIL. Ministério da Agricultura, Pecuária e Abastecimento. Instrução Normativa $\mathrm{n}^{\circ} 62$, de 26 agosto de 2003. Oficializa os Métodos Analíticos Oficiais para Análises Microbiológicas para Controle de Produtos de Origem Animal e Água. Diário Oficial da União, Brasília, 26 de agosto de 2003. Seção 1.

BRASIL. Ministério da Agricultura Pecuária e Abastecimento. Instrução Normativa $\mathrm{n}^{\circ} 68$, de 12 de dezembro de 2006. Oficializa os Métodos Analíticos Oficiais Físico-Químicos para o controle de leite e produtos lácteos. Diário Oficial da União, Brasília, 14 de dezembro de 2006, Seção 1.

CASERIO, G.; SENESI, E.; FORLANI, M.; EMALDI, G. Condizioni igieniche delle Mozzarelle in rapporto alla tecnologia di produzione. L'Industria del latte, v.2, p.19-39, 1977.

CENTRO PANAMERICANO DE ZOONOSIS. Manual de normas y procedimentos técnicos para la bacteriología de la tuberculosis. Buenos Aires: OPA/OMS, 1985. 25p.

DONAGHY, J.A.; TOTTON, N.L; ROWE, M.T. Evaluation of culture media for the recovery of Mycobacterium avium subsp. paratuberculosis from Cheddar cheese. Lett. Appl. Microbiol., v.37, p.285-291, 2003. 
ECKNER, K.F.; ROBERTS, R.F.; STRANTZ, A.A.; ZOTTOLA, E.A. Characterization and behavior of Salmonella javiana during Manufacture of mozzarella type cheese. J. Food .Prot., v.53, p.461-464,1990.

GRANT, I.R.; BALL, H.J.; ROWE, M.T. Thermal inactivation of several Mycobacterium spp. in milk by pasteurization. Lett. Appl. Microbiol., v.22, p.253-256, 1996.

HARRINGTON, R.; KARLSON, A.G. A destruction of various kinds of mycobacteria in milk by pasteurization. Appl. Microbiol., v.13, p.494-495, 1965.

JAY, J.M. Modern Food Microbiology. 2.Ed. Nova York: CHAPMAN \& HALL, 1996. 661p.

KELLS, H.R.; LEAR, S.A. Thermal death time curve of Mycobacterium tuberculosis var. Bovis in artificially infected milk. Appl. Microbiol., v.8, p.234-236, 1960.

KIM，J.; SCHMIDT, K.A.; PHEBUS, R.K.; JEON, I.J. Time and temperature of stretching as critical control points for Listeria monocytogenes during production of mozzarella cheese. J. Food Prot., v.61, p.116-118, 1998.

KONEMAN, E.W.; ALLEN, S.D.; JANDA, W.M. et al. Micobactérias. In: KONEMAN, E.W.; ALLEN, S.D.; JANDA, W.M. et al. Diagnóstico microbiológico. 5ed. Rio de Janeiro: MEDSI, 2001. p.903-946.

MACDONALD, F.; SUTHERLAND, A.D. Effect of heat treatment on Listeria monocytogenes and Gram negative bacteria sheep, cow and goat milks. J. Appl. Microbiol., v.4, p.336-343, 1993.

NISHIMOTO, E.J. Efeito da gordura do leite de vaca sobre o valor $D 65^{\circ} \mathrm{C}$ do Mycobacterium fortuitum (NCTN 8573). 2006. 81f. Dissertação (Mestrado em Medicina Veterinária) - Faculdade de Medicina Veterinária e Zootecnia, Universidade de São Paulo, São Paulo.

PAOLICCHI, F.A. Paratuberculosis: implicancia zoonótica com la enfermedad de Crohn em humanos. In: CACCHIONE, R.A.; DURLACH, R.; MARTINO, P. Temas de Zoonosis IV. Buenos Aires: ASSOCICIÓN ARGENTINA DE ZOONOSIS, 2008. p.273-284.
SILVA, E.O.T.R.. Fabricação artesanal de mozzarella elaborada com leite cru de búfala. Estudo da contaminação microbiológica associada à manipulação em produção manual ou parcialmente mecanizada. 1997. 47f. Dissertação (Mestrado em Medicina Veterinária) - Faculdade de Medicina Veterinária e Zootecnia, Universidade de São Paulo, São Paulo.

SILVA, E.O.T.R.; PANETTA, J.C.; ISHIZUKA, M.M. Efeito microbiocida da fase de filagem durante a fabricação de "mozzarella" elaborada com leite cru de búfala. Rev. Hig. Aliment., v.13, p.28-34, 1999.

SPANO, G.; GOFFREDO, E.; BENEDUCE, L. et al. Fate of Escherichia coli O157:H7 during the manufacture of mozzarella cheese. Lett. Appl. Microbiol., v.36, p.73-76, 2003.

STARIKOFF, K.R. Efeito da gordura do leite de cabra sobre o valor $D 65^{\circ} \mathrm{C}$ do Mycobacterium fortuitum (NCTN 8573). 2006. 83f. Dissertação (Mestrado em Medicina Veterinária) - Faculdade de Medicina Veterinária e Zootecnia, Universidade de São Paulo, São Paulo.

VILLANI, F.; PEPE, O.; MAURIELLO, G.; MOSCHETTI, G. et al. Behavior of Listeria monocytogenes during the traditional manufacturing of water buffalo Mozzarella cheese. Lett. Appl. Microbiol., v.22, p.357-360, 1996.

WALSTRA, P.; GEURTS, T.J.; NOOMEN, A.; et al. Dairy technology: principles on milk properties and processes. New York: Marcel Dekker Inc, 1999. 727p.

WHO - World Health Organization. Guidelines on disinfection in animal husbandry for prevention and control of zoonotic diseases. Geneva: WHO, 1984. p.49. 